\title{
Pecado estructural. Pecado del mundo
}

\author{
JOSE IGNACIO GONZALEZ FAUS \\ Sant Cugat del Vallés, Barcelona.
}

\section{Introducción}

\section{Enmascaramiento y estructuración del pecado*}

El pecado tiene un aspecto personal e imputable; pero, a la vez, tiene un aspecto enmascarador $y$, en este sentido, a-nónimo o impersonal al cual el pecado humano recurre para poder afirmarse. Cualquier reflexión teológica tiene que dar cuenta de esos dos aspectos del pecado que más bien parecerían excluirse.

Cualquier explicación de la maldad humana que no diera suficiente cuenta de esa capacidad de enmascaramiento, debería resultarnos por eso mismo sospechosa. Mientras que, allí donde esa capacidad de enmascaramiento se explique y tenga cabida, hay un indicio de que quizás estamos acercándonos a lo que realmente ocurre con la pecaminosidad humana.

Estas consideraciones elementales son las que introducen el tema del llamado "pecado estructural" o ambiental, el cual es un componente decisivo e imprescindible de la noción cristiana y teológica de pecado original. El pecado se puede enmascarar porque no solamente constituye nuestra a-normalidad y nuestra aberración, sino tambièn porque constituye nuestra atmósfera y nuestra normalidad. El pecado no es nuestra locura insólita sino, en todo caso, lo que un afortunado título de película calificaba como nuestra "ordinaria locura."

- Este articulo es parte de un libro en gestación sobre antropología teológica. El tema del articulo presupone como ya tratado el tema del pecado personal, y supone que el tema del pecado estructural se completará con el tratamiento del pecado en la historia. El artículo analiza el pecado del mundo como pecado estructural y en ello se centra. 
Esto significa -entrando ahora en descripciones sicológicas elementales - que el hombre rara vez pecará por amor al mal y queriendo precisamente pecar. Esa visión del mal, que es la que solemos tener (y por eso encontramos tan raramente al pecado), sólo refleja lo que puede ocurrir en situaciones de una lucidez casi anormal (o "angélica") y que muy difícilmente puede alcanzarse. Pues el hombre no es "decisión sola," sino decisión rodeada por un ambiente; ni es tampoco equidistancia indiferente entre bien y mal, sino inserción incomprensible en los dos: es bueno y malo a la vez. Pero de tal manera que, como muy bien escribió K. Rahner, "el hombre es siempre un mal santo y un mal criminal."

Esta complejidad del "mal santo" y del "mal criminal" es lo que hay que explicar. Los antiguos escolásticos solían decir que el mal se comete siempre sub specie boni, sub aspectu boni, es decir, por el bien que realmente contiene o parecer contener. Los hombres, en cambio, solemos pensar que, para obrar mal, hace falta hacer el mal sub specie mali, algo asi como hacen los célebres personajes del marqués de Sade en sus incesantes justificaciones y elucubraciones sobre los propios actos:

para que una imagen sexual resulte atractiva es preciso asociarla a una idea libertina...

¿Hay acaso necesidad de pretextos para cometer un delito?...

La primera ley que me dicla la naluraleza es la de deleitarme no importa a costa de qué o de quién. Si la naluraleza ha dado a mis órganos una constitución tal que sólo en la desgracia de mi prójimo puede aflorar mi satisfacción, es señal de que necesita un ser como yo para servir a sus planes... etc. etc.'

Sade pinta monstruos humanos que, en teoría, parecen argumentar con el ideal de la pura racionalidad, llevada hasta sus últimas consecuencias lógicas. Lo que ocurre es que, en el ser humano, nunca se da esa pura racionalidad. 2 Son personajes que optan por el mal desde la más pura neutralidad, sin estar en absoluto inficionados, sin ningún condicionamiento exterior o ambiental. De este modo aparecen como monstruos, y vienen a resultar un ejercicio de antropologia-ficción o, mejor, de "inmoralidad-ficción." Pero, por eso mismo, dejan de ser impactantes y dispensan al hombre de reconocerse en ellos, dándole más bien una cierta tranquilidad respecto de si mismo. Pero esa tranquilidad no está del todo justificada: quizás sólo muestra que la maldad humana no es una satánica maldad de superhombre; pero no excluye el que pueda ser una gran maldad de cobarde, o de víctima.

En efecto, lo espantoso de nuestro siglo $\mathrm{XX}$ es que cree haber conocido monstruos de calibre similar al de los pintados por el márques de Sade. Sólo que tales monstruos razonaban de manera muy distinta. Pensemos en los generales argentinos y las infinitas pesadillas develadas por el informe Sábbato; los militares guatemaltecos en esa cínica sucesión de pesudopromesas que se perpetúa desde 1954; las tristemente célebres "catorce familias" de El Salvador; la imagen de Pinochet comulgando, que cada septiembre nos sirve fielmente la televisión; la minoría blanca en el poder de Sudáfrica; los refinamien- 
tos de un estalinismo bien organizado; la lógica sin miedo de una pesadilla como la de Camboya... No soy yo el primero en afirmar que Sade habría disfrutado de poder describir esas formas de tortura, de homicidio, de desaparición. $\mathrm{Y}$, sin embargo, - a pesar de semejanzas materiales- la diferencia con los personajes del neurótico marqués es muy grande: ninguno de esos personajes reales se ha dicho nunca a sí mismo como los personajes de Sade: "voy a ser una bestia hasta el final." Si se hubiesen dicho eso a si mismos, no se soportarían, como no soportan que nadie se los diga: ellos mantienen en pie la contienda sobre su honorabilidad, y esto los hace, a la vez, más mezquinos, pero también menos irredentos que los personajes de Sade. Porque ellos no se dijeron: "voy a ser una bestia hasta el final." Ellos se dijeron simplemente: "vamos a matar comunistas." 3

Y esta es la diferencia fundamental. El que dice: "voy a matar comunistas" no está - por así decirlo - creando él solo el mal desde la nada. Está participando en un mal ya "estructurado," establecido en toda una red de valores (y, por lo tanto, "positivizado"), de la cual él es fruto y víctima pasiva, pero a la cual él, a su vez, contribuye a tejer y a fortificar, al darle "nudos" personales sin los cuales no se aguantaría la estructura. ${ }^{4}$

Esta es, entonces, la importancia del tema del pecado estructural, el cual no se opone ni merma al pecado personal, pero puede quizás ayudar a comprenderlo. Y es de temer que la predicación cristiana (calólica y protestante), por el afán de salvar la importancia de lo personal del pecado, haya oscurecido el tema del pecado estructural, perjudicando de rechazo aquello mismo que quería salvar. Porque entonces, para que los hombres se sintieran profundamente pecadores, tenian que reconocerse en los personajes del marqués de Sade, lo cual ya hemos visto que era muy improbable o absolutamente ocasional. En cambio, si se nos hubiese pedido reconocernos en los militares argentinos, o en las catorce familias salvadoreñas, quizás más fácilmente habriamos bajado los ojos avergonzados. ${ }^{5}$

Que "todos somos pecadores" (Rom. 3,23) o que todos llevamos dentro monstruos de antifraternidad, no quiere decir, pues que todos seamos "casos extremos" o que razonemos como los textos citados en la nota 1.

Y esto mismo puede formularse también cristológicamente: es a través del pecado estructural como actuó el pecado personal de quienes mataron a Jesús; no actuó sin mediaciones, como una makdad refinada y químicamente pura (o "sádica"). Por eso, en su apariencia, la muerte del Hijo (es decir, el pecado máximo al que todo otro pecado se remite: cl. Heb. 6,6 y 10,29) no fue una victoria de la inmoralidad sobre la moralidad del Justo, sino que fue la lucha entre dos "moralidades;" los judíos pueden matar a Jesús en el seno de su "moral" estructurada, de esa misma moral que les impide echar en el Corban un dinero que es precio de sangre y los obliga a deliberar para ver lo que hacen con él (cᄃ. Mt. 27,6ss); la misma moral que les impide condenar a madie sin coincidencia unánime de testigos (cf. Mc. 14,59) o les prohíbe entrar en casa de un pagano aunque sea para obtener aquello tan vital para ellos como era el verse libres de un peligro público (cf. Jn. 18,28). La escrupulosa actuación de quienes matan a Jesús no es el satánico ensimismamiento del mal que tienen 
los personajes de Sade, por muy personalmente culpables que fuesen los agentes de aquella muerte del Mesías. Y repito, aquella muerte de Jesús es un poco como el paradigma de todo pecado. Quizás por eso el Jesús de los evangelios nunca se indigna ni grita contra "la maldad" en sí misma; pero se estremece y clama repetidas veces contra "la dureza de corazón" y contra la "hipoctesía" (cf. Mc. 3,5; Lc. 12,1; Mt. 15,17; 23,14.15 entre otros).

Es, pues, en nuestra normalidad relacional de cada dia, donde la antifraternidad está instalada y donde anida sub specie boni. Como fue en la relación de Eva con la serpiente donde se instaló la visión del fruto del árbol como bueno y apetitoso y deseable (cf. Gen. 3,5.6). Este tema es, por lo tanto, el que hay que examinar.

\section{La noción bíblica de pecado del mundo}

Desde el punto de vista biblico, hay una noción muy afin a lo que nosotros acabamos de llamar "pecado estructural" y es la noción de "pecado del mundo," acuñada por el cuarto evangelio, y que ocupa en él un lugar decisivo. Vamos a tratar de seguirla en su aparición y de fijar un poco sus rasgos.

\subsection{Establecimiento del concepto de "pecado del mundo"}

Dos rasgos, en el exordio de este evangelio, nos introducen a la idea del pecado del mundo. Por un lado, el evangelio se abre con una especie de aforismo enormemente genérico, y casi atemporal, como los tres capitulos primeros del Génesis, que define de una manera estructurante la relación entre la comunicación de Dios (la Palabra que es verdad y vida) y el género humano. Y ésta es precisamente una relación de oposicion: "el mundo no lo ha conocido" (Jn. $1,10)$. Por otro lado, y en paralelo con el prólogo que presentaba al Logos como el desconocido por el mundo, nos encontramos con que el capítulo primero, historiza ya esa presentación definiendo a Jesús como "el que carga con el pecado del mundo" (ho airôn tèn hamartian toû kósmou, Jn. 1,29). Esta frase reclama un mínimo análisis para fijar su correcta traducción.

En primer lugar, es lástima que nuestro lenguaje litúrgico ("quitar los pecados del mundo") nos haya hecho perder la fuerza del singular original. Lo que quita el Cordero (o El Siervo ${ }^{6}$ ) de Dios, no son los "actos," sino la fuente unitaria de esos actos: el pecado.

Además de eso, la traducción "quitar" es cuanto menos precipitada, puesto que, tanto la alusión manifiesta a Isaías 53, como el significado del griego aireô (y del hebreo saba) incluyen como primario el significado de "llevar" o "cargar con." El cordero quita el pecado del mundo al cargar con él. La muerte de Jesús será la asunción del pecado del mundo: será, pues, efecto del pecado del mundo y no sólo de los pecados de unas personas particulares (aunque es a través de esos pecados particulares como actuó el pecado del mundo en la muerte del Señor). 
Y, finalmente, además del "quitar" y de "el pecado," es preciso aclarar la palabra mundo. Es sabido que ese mundo se contrapone a la misma palabra (kosmos), usada por el cuarto evangelio en otras muchas ocasiones, con significado positivo. Hay un mundo al cual Dios "lo amó tanto que le envió a su Hijo no para condenarlo sino para salvarlo" (cf. 3,16.17) y hay también un mundo por el cual Jesús ni tan sólo quiere rogar $(\mathrm{Jn} .17,9)$. Ambos merecen, no obstante, el mismo nombre: mundo. El sistema cosmológico-humano, en cuanto creación de Dios y sede del proyecto de filiación-fraternidad, es el mundo amado por Dios. La implantación del pecado en ese sistema, que lo convierte en un proyecto de autodivinización y enemistad, es lo que representa la palabra mundo en su sentido negativo.

Ahora bien, tal como ocurre con la palabra "creación" en Pablo (Rom. 8,19), aqui la palabra mundo puede traducirse como "la humanidad." Mundo es, entonces, "la humanidad en cuanto estructurada en un orden sociorreligioso enemigo de Dios." " Jesús es presentado como quién carga con el pecado del mundo, y esta presentación engloba toda la historia posterior de Jesús, en la cual el conflicto inmediato y, por así decirlo, anecdótico, no parecerá ser conflicto con "el mundo," sino con "los judios." Pero esta forma de presentarlo nos hace ver que "los judios" son sólo un paradigma o instrumento de ese sistema enemigo de Dios y del hombre que, como tal, rebasa el ámbito judío. "Lo que caracteriza en el cuarto evangelio a los componentes del mundo no es ser judios de raza, sino ser enemigos del hombre por constituir un sistema opresor." "B Los judíos obran como obran porque "son del mundo" (Jn. 8,23).

Con ello tenemos establecida la noción joánica: hay un "pecado del mundo" o "pecado de la humanidad," el cual constituye nada menos que el polo dialéctico de la figura de Jesús. De esta noción se derivan, a lo largo del cuarto evangelio, algunas observaciones teológicas de interés.

\subsection{Contenido del pecado del mundo}

Estas observaciones pueden reducirse en mi opinión a tres capítulos, atendiendo a lo que dicen sobre el mundo, lo que dicen sobre el hombre (en su relación al mundo) y lo que dicen sobre Cristo (y sobre el hombre en su relación a Cristo).

Si el mundo es pecado implantado o pecado estructural, se comprende que luego sus obras sean malas (Jn. 7,7). Y se comprende también que esa maldad, al coincidir con la totalidad del sistema, quede por eso mismo encubierta y necesite ser desenmascarada. Por eso, el mismo Jesús dirá del mundo que no puede soportar la verdad: "ni ve ni conoce el espiritu de la verdad" (Jn. $14,17)$. Esa incapacidad radica en que el mundo no conoce a Dios en cuanto es precisamente Padre y Justo (cf. Jn. 17,25). Por eso mismo los valores del mundo son contrarios al reino de Dios: que "el reino no es de este mundo" $(18,36)$ no significa meramente una caracterización "cronológica" (es decir, que vendrá después de esta historia), sino sobre todo una caracterización axiológica, no se construye con los criterios y valores constitutivos de este orden presente. ${ }^{9}$ 
En segundo lugar, si los hombres obran el mal, es porque son hijos o miembros de esa humanidad empecatada la cual es sede primaria del mal (Jn. 8,23 y 17,15 ). Desde esta perspectiva se vuelve coherente la afirmación de que este "mundo" o pecado estructurado tiene un "jefe" o un "príncipe" (archon, Jn. 12,31; 14,30;16,11), dado que cada hombre no es en realidad dueño absoluto del mundo, sino más bien su víctima. ${ }^{10}$

La misión de Jesús consiste en tercer lugar, en poder cambiar esa filiación de los hombres y liberarlos de la necesidad de ser "hijos de este mundo" (cf. 15,19 y 17,15). Jesús realiza esa misión en un triple paso. Como revelador de esa maldad del mundo. Primero con su propio testimonio (Jn, 7,7; 15,22), pero luego con el hecho mismo de su muerte, en ella este mundo queda desenmascarado como aquél que necesariamente echa fuera al Justo y al Profeta (cf. 12,31-33 y 16,11). En segundo lugar, como el condenador de este mundo. Con un juicio de condena que ahora invierte el juicio del mundo: los lúcidos de acuerdo con el mundo son declarados ciegos. Y los ciegos según el mundo son precisamente los que conseguirán ver (cf. 9,39). El hecho de Jesús trastueca los juicios de ese pecado estructural que es el mundo. En tercer lugar como el odiado por el mundo. Pues frente a los dos puntos anteriores, el mundo responde odiando a Jesús $(\mathrm{Jn} .7,7)$ y a los suyos $(15,19 ; 17,14)$ y condenándolos a su vez. Dado este odio, a lodo aquél que viva como Jesús en medio de ese pecado estructural, no le queda más salida que el sufrimiento y la persecución (cf. 16,20 y 33). Pero, a la vez, ese sufrimiento se revelará como salvación, puesto que amar la propia vida en una estructura como la que hemos descrito equivaldría a perderla $(12,25)$. Esta es la razón de por qué, para Juan, la narración de la pasión de Jesús se convierte en un relato tan triunfal y glorioso.

Y este triple paso que ha inaugurado la misión de Jesús, se actualiza luego en la fe, por la acción del Espíritu sobre cada seguidor. Por eso, el Espíritu, según Juan, "convence al mundo" de tres cosas: a) de un pecado que consiste en no adherirse a Cristo y en dar su fe a un sistema contrario a Cristo (Jn. 16,9); b) de dónde está la verdadera justicia, la cual no está en el juicio del mundo, sino en el de Jesús; puesto que Jesús es quien es acogido por el Padre, y no el mundo $(16,10) ; c)$ y de una condena porque, a partir de la condena de Jesús, el principio estructurador de este mundo ha quedado puesto en evidencia $(16,11)$. La correspondencia entre esta triple tarea del Espíritu (que tantos quebraderos de cabeza suele crear a los traductores) y el triple paso de la misión de Jesús -que hemos enunciado antes - es tan total como sorprendente.

En resumen, pues, el mundo como pecado estructural es contrario al reino de Dios y a su justicia. Las hombres son frutos o victimas del pecado del mundo. Jesús es desenmascarador del pecado estructural, y revelador del juicio de Dios contra él; pero lo es a costa de su pasión. De este modo ofrece la posibilidad de desolidarizarse del pecado del mundo, muriendo a sus manas.

Esta breve teología es, en mi opinión, enormemente seria. De acuerdo con ella, ser cristiano (o creer en Jesús que es lo mismo) consistiría para el cuarto evangelio en la seguridad de que Dios está contra el pecado del mundo; en la consecuente condena personal de ese pecado, junto a una vida coherente con esa condena, y, por último, en soportar las consecuencias de esa condena 
hecha por la propia vida al pecado estruclural. Estas consecuencias vendrán impuestas por cualesquiera de los poderes de este mundo, los cuales son necesariamente gestores del pecado estructural. Y el segundo de estos puntos (la condena del pecado estructural y la vida coherente con ella), puede ser aún más concretado por nosotros con relativa facilidad: ser de Jesús o creer en Jesús (es decir, la única manera de combatir el pecado estructural para Juan) será colocarse siempre de parte, y verlo todo siempre desde el lado de las victimas del mundo y de las víctimas de cada situación concreta. Se trata de colocarse contra aquello que rompe la fraternidad y crea lo que los hombres solemos llamar victimas. Esta tarea no será en si misma fácil, pues no slempre es sencillo discernir si alguien es realmente víctima o se victimaliza a sí mismo para oprimir a los demás (hasta ahi pueden llegar los tentáculos del pecado). Pero, en cualquier caso, es evidente que el colocarse siempre en el lugar de las victimas de cada situación y mirarlo y valorarlo todo desde esas viclimas, es lo que poco a poco irá convirtiendo al hombre en una nueva victima del orden presente. Víctima esta vez no a la manera como dijimos que lo es cada hombre, es decir, como fruto y como "hijo" del sistema, sino a la manera como lo fue Jesús, como mártir del sistema y como rechazado por él.

\section{La noción de pecado estructural en Medellín y Puebla}

Para encontrar en el magisterio de la lglesia alguna enseñanza que parezca retomar la doctrina joánica sobre el pecado del mundo, o al menos referirse a ella, acudiremos a las dos últimas asambleas del episcopado latinoamericano, en Medellín (1968) y Puebla (1979). En ambas vamos a encontrar una expresión que brota de la enseñanza del cuarto evangelio, aunque ésta ha sido rechazada por algunos, y aunque es innegable que Medellin y Puebla hacen de ella un uso más restringido, y referido casi sólo al campo económico. Se trata de la expresión "pecado estructural," que ha dado título al presente capítulo.

En nuestra exposición vamos más allá de la acuñación primariamente económica, porque los intereses de este tratado son lógicamente más amplios que los de una asamblea episcopal. A nosotros nos interesa mostrar que el pecado se implanta no sólo en las estructuras económicas, sino en todas las demás: en las sociopoliticas, culturales, religiosas, etc., en todo lo que constituye "el mundo" del hombre. Pero quisiera dejar constancia de que me parece legitimo el uso preferentemente económico que hacen Medellin y Puebla del pecado estructural. Y ello por tres razones. Porque, tanto en 1968 como en 1979, estaba ahí el problema más angustioso con el que se debatia la gran mayoria del pueblo latinoamericano. Porque ése era además el pecado más negado y que más necesitaba ser desenmascarado. Y porque, como dijo Pablo VI en uno de sus discursos en Colombia, la Iglesia estaba obligada a "escuchar el clamor de su pueblo." Pretender que con esa aplicación, Medellin o Puebla habian operado un reduccionismo, seria tan blasfemo como acusar de reduccionista al Dios del éxodo, cuando se revela como escuchando el clamor de su pueblo oprimido (Ex.3,7). Es innegable que en el ser humano existen además otros clamores que los provocados por la opresión de un pueblo sobre otro. Pero 
utilizar este dato como argumento para desoir ese clamor concreto, o para acusar de reduccionista a quienes tratan de escucharlo, es algo que sólo puede hacerse desde la mala fe.

Hecha esta aclaración, vamos al lenguaje de Medellín y Puebla. Primero reproducimos los textos de ambas asambleas, para comentarlos a continuación.

En la introducción a los documentos de Medellín, hablando de las condiciones de vida menos humanas que soportan los latinoamericanos, se señalan

las estructuras opresoras que provienen del abuso del tener y del abuso del poder, de las explotaciones de los trabajadores o de la injusticia de las transacciones (No. 6). 11

A su vez, en el documento de Medellín sobre la justicia se describe el siguiente proceso del obrar humano:

La falta de solidaridad lleva en el plano individual y social a cometer verdaderos pecados, cuya cristalización aparece evidente en las estructuras injustas que caracterizan la situación en América Latina (Justicia 2).

Y finalmente, en el documento sobre la paz, se constata que hay una serie de factores

que expresan una situación de injusticia, o realidades que expresan una situación de pecado (No. 1),

hasta tal exiremo que la "tirania evidente y prolongada" de que hablaba el No. 31 de la Populorum Progressio, opina Medellín que

puede provenir tanto de una persona como de estructuras evidentemente injustas (No. 19).

Estructuras opresoras, estructuras injustas, situación de injusticia, o situación de pecado, parecen ser expresiones sinónimas que aluden a la misma realidad del pecado estructural. Veamos ahora cómo habla Puebla. Y es importante notar que Puebla no se apartó de este lenguaje, a pesar de las resistencias y acusaciones hechas por algunos a raíz de Medellin:

El pecado, fuerza de ruptura, obstaculiza permanentemente el crecimiento en el amor y la comunión, tanto desde el corazón de los hombres como desde las diversas estructuras por ellos creadas, en las cuales el pecado de sus autores ha impreso su huella destructora (281).

Para poder mantener este lenguaje, Puebla recurre al Papa Juan Pablo Il (citado inmediatamente a continuación) quien, en su homilia en Zapopan, habia dicho de María que "ella nos permite superar las múltiples estructuras de pecado." La expresión "estructura de pecado" es quizás la más tajante de todas las que hemos reseñado hasta ahora. El papa puede presentar asía Maria porque para ella "sólo cuenta la voluntad de Dios," "por encima de las circunstancias adversas de la vida personal y social." 12

Una vez citados los textos trataremos ahora de analizarlos. En Medellin se contienen sustancialmente tres afirmaciones que vamos a exponer buscando su formulación más nítida y más simple, proponiéndolas en forma de columnas, para poder añadir al margen variantes o comentarios. 
Primera afirmación:

-el pecado

-cristaliza

-en estructuras injustas

Segunda afirmación:

- Estas estructuras

- Llevan a la mayoría de los hombres

- a condiciones de vida infrahumanas.

Tercera afirmación: por consiguiente,

- La injusticia evidente y prolongada

-puede provenir (tanto de una persona como)

Estas tres afirmaciones resumen las enseñanzas de Medellin. La doctrina de Puebla puede reducirse a otras dos afirmaciones, que intentaremos presentar con una disposición tipográfica parecida.

Primera afirmación:

-El pecado

-impide la fraternidad

- tantos desde el interior del hombre,

-como desde el "exterior." (es decir, la falta de solidaridad, el abuso del poder y del tener...).

(o, estrucluras opresoras, o, situaciones de injusticia y situaciones de pecado).

(Estas condiciones "menos humanas" equivalen a antifraternas, pues si en unos implican "la carencia material del mínimo vital," en otros implican "la carencia moral de los que están mutilados por el egoísmo").

(que justificaría una legítima defensa incluso violenta)

de estructuras evidentemente injustas. 
Segunda afirmación:

- Pues ese "exterior" es, a la vez:

-fruto de los hombres pecadores

-en el que está impresa la huella destructora del pecado.

Prescindiendo de la tercera afirmación de Medellin, que ahora no hace al caso, es fácil ver que se da una coincidencia o igualdad práctica de la primera afirmación de cada grupo con la segunda del otro. Que "el pecado cristaliza en estructuras injustas" equivale a decir que "en las estructuras creadas por los hombres está impresa la huella del pecado." Que "las estructuras llevan a condiciones de vida infrahumanas," se corresponde con que "el pecado impide la fraternidad tanto desde el corazón como desde las estructuras." En resumen, pues, el hombre, al pecar, crea "situaciones de pecado" que, a su vez, hacen pecar al hombre. ${ }^{13}$ Este círculo es fundamental para nosotros. El pecado estructural no nace de la nada ni es antecendente al hombre, nace del hombre mismo. Pero, una vez nacido, se escapa al control del hombre, se convierte en una fuerza autónoma frente a él, domina al hombre y hace que ya no pueda reducirse el estudio del pecado al aspecto puramente personal. ${ }^{14}$

Esto significa que todo aquello que relaciona y une socialmente a los hombres (usos, valores e ideologías, juegos de necesidades y conveniencias) no es siempre ni necesariamente neutral. Más aún habría que decir que casi nunca es bueno, suele ser pecado objetivado. ¿Por qué? Ni Medellín ni Puebla ni San Juan abordan la respuesta a esta cuestión fundamental. Tampoco era esa su tarea. Pero nosotros estamos obligados a buscarla y con este fin sugerimos las consideraciones que siguen.

\section{Reflexión teológica}

La convivencia humana es siempre un hecho activo y pasivo a la vez. Los hombres entablan la convivencia, pero también van siendo poco a poco marcados y condicionados por ella. Es como una pared de frontón que le devuelve al hombre los mismos movimientos que él ha impreso a la pelota. Hablar de pecado estructural quiere decir, por lo tanto, que el pecado se hace presente en esta circularidad que Medellin y Puebla supieron percibir muy bien. Y por eso, para subdividir nuestras reflexiones vamos a recordar una antigua terminologia que se hizo clásica, y en la cual se expresaba ese doble sentido activo y pasivo. Hablaremos asi de pecado estructurante y de pecado estructurado.

\subsection{El pecado estructurante}

Al revés de lo que puede esperarse en la relación personal (vg. en el amor o en la amistad) es muy frecuente que, en la relación social, el hombre sólo piense en sí mismo y en su provecho y que - al menos mayoritariamente- la entable sólo por sí mismo. El individuo sospecha además que los otros actuarán 
de igual modo y pensarán sólo en ellos, con lo cual la conducta egoista se refuerza, y cabe esperar que la relación social esté naturalmente entablada de este modo viciado. Incluso, por si fuera poco, los mismos hombres se animan a él con el conocido argumento de que aunque cada cual piense sólo en sí mismo, hay una "mano invisible" que armonizará el egoismo de todos. Esa supuesta "mano invisible" es como la persuasión de la serpiente que hace ver el fruto del árbol prohibido como "bueno y deseable." Pero sus efectos no son ésos, pues siempre que el hombre piensa sólo en sí y actúa sólo por sí, se produce una lesión de lo fraterno; esa lesión de lo fraterno acaba por fructificar haciéndose perceptible algún día. La misma paradoja que es el hombre puede explicar cómo se produce esa lesión de lo fraterno. Al actuar así, al pensar sólo en sí, el hombre se endiosa y cree actuar "como Dios." Pero en realidad se destroza puesto que la "imagen de Dios" que lleva dentro es precisamente la semilla de la comunión y la fraternidad.

El pecado se implanta, pues, en el paso de "el hombre" a "la humanidad." Pero esta frase no tiene el sentido supuestamente rousseauniano de que el individuo sea bueno y la sociedad mala. ${ }^{15}$ La sociedad es más bien la puesta a prueba que el individuo no resiste, porque pretende "ser como Dios." Por consiguiente, que el pecado aparezca en las estructuras de convivencia no significa que nazca con ellas. Al revés, se implanta en el hecho social porque está ya dentro del hecho individual, posibilitado por la labilidad del hombre. El pecado se hace posible en el riesgo que supone la alteridad, y por lo tanto, la Traternidad, para un ser que se vivencia a si mismo como "divino" y que tiende a concebir esa propia dignidad que percibe, como un ser-centro, ser-único, ser inafectable o ser el primero.

O con otras palabras, precisamente por esa pretensión divina que lleva dentro cada hombre, no existe en las relaciones humanas una "armonía de intereses" habitual o estructural y espontánea. En éstas habrá más bien una tendencia grande no a la armonía, sino a la absolutización de intereses. Y la "mano invisible" no es efectivamente, sino "la voz de la serpiente."

El pecado estructural se extiende a las estructuras de relación económica, pero también a toda esa red de relaciones que, en sentido amplio, podemos denominar "cultura," es decir, a todas las estructuras del hecho social humano; aun a las más necesarias y a las mejores de ellas, a la patria, a la religión, al progreso... ${ }^{16} \mathrm{Y}$ el hombre, aunque lo necesite, no puede entregarse incondjcionalmente a estas realidades ni identificarse incondicionalmente con ellas, porque todas ellas son, sí, valores, pero valores tarados.

\subsection{El pecado esiructurado}

Veamos ahora la voz pasiva de lo anterior. A todo ser personal humano le es intrinseco un ser socialmente situado. Ser persona implica necesariamente tener un entorno. Es un tópico casi necesario evocar aquí las conocidas deliniciones de Ortega y Gasset: ("yo soy yo y mi circunstancia") o de M. Heidegger: ("el existente humano es un ser-en-el-mundo"). 
Ahora bien, el entorno del hombre son, en última instancia, los demás hombres. Pero la relación social con ellos se verifica a través de todo ese conjunto de mediaciones a las que venimos llamando "estructuras." Así, nuestro entorno está constituído por valores, ideologias u objetivos comunes, pues sin un mínimo de éstos - aunque sea sólo el valor compartido del respeto por los que no piensan igual y del derecho de cada cual a pensar como quiera- ya no puede haber mundo ni entorno. Está hecho también por un flujo de influjos y hasta "ejemplos" o incitaciones mutuas que brotan del hecho de que cada vida es vida ante los demás. Está hecho igualmente por una serie de necesidades o demandas coincidentes y objetivadas y de prácticas que esas necesidades generan (comercio, viajes, relaciones laborales y mil cosas más).

Afirmar el pecado estructural equivale a reconocer que es en ese entorno (el cual no es en si mismo personal, pero es constituyente de la persona), donde se implanta el mal; que todas esas formas configuradoras de la relación social no son fruto de la fraternidad y que, por lo tanto, en ellas no está implantada la fraternidad, sino que hay implantados gérmenes que luego la harán casi imposible en las relaciones concretas. Lo antifraterno llegará por ahi hasta el núcleo mismo de la persona, puesto que el hombre está hecho para identificarse con ese entorno que le permite ser, y para desplegarse a partir de él. $O$ con otras palabras, en la medida en que el entorno le es constitutivo, todo hombre estará ya en el camino paulino que lleva de la hamartia (el pecado como fuerza personificada) a la paraptômata (lo que nosotros llamamos "pecados" o transgresiones concretas).

La fraternidad, por eso, habrá de surgir muchas veces contra la corriente del entorno, contra la ley de gravedad de esas estructuras antifraternas; emergiendo desde ellas en pequeñas conquistas, personales o grupales, pero nunca totales. Quiere esto decir que el empeño por un cambio de las estructuras del humano convivir, para hacerlas más fraternas -es decir, más hijas de la fraternidad y más favorecedoras de ella- es, como se ve, un empeño absolutamente necesario, legitimo y noble; y empeño de siempre. Pero es un empeño que sólo podrá ganar pequeños espacios y pequeños pasos adelante (muy valiosos, eso sí, a pesar de su pequeñez) y quizás sólo provisionales o, al menos, perpetuamente amenazados.

Sin pretensiones de exhaustividad, vamos a examinar un poco más esos tres ejemplos que acabamos de enumerar como estructuradores de la comunidad humana y como sede del pecado estructurado: las ideologías y valores, los influjos y ejemplos, las necesidades y prácticas establecidas en la convivencia. Este examen nos mostrará cómo todo pecado personal o conjunto de ellos, nunca puede ser considerado en su sola realidad personal o suma de realidades personales, sino que, además de eso, influye en el mundo viciando la atmósfera (a esto le podemos llamar con Teilhard la hamartiosfera); influye en otros particulares seduciéndolos o minándoles el terreno (a esto el evangelio suele llamarle escándalo) y además de eso influye en la historia o marcha de la humanidad, haciendo que sea necesario dar nuevos pasos falsos en esa marcha (es lo que se llaman "huidas hacia adelante") y cometer nuevas rupturas de la fraternidad, para que esa humanidad pueda seguir caminando ( $y$ a esto deberíamos llamarle "pecadicción" o hamartiomania). 
Repito que los tres casos están elegidos como ejemplos sólo y sin pretensiones de agotar con ellos el tema. Pero ellos nos harán ver que, asi como el pecado personal es una falsificación del hombre, hemos de decir ahora que el pecado-del-mundo o pecado estructural es una falsificación de las estructuras humanas de convivencia y, por tanto, una falsificación del hecho social.

\subsubsection{La mentira implantada o el pecado como "ideología"}

Uno de los aspectos principales de esta falsificación consiste en que toda sociedad tiene una red de intereses (o de pasiones), la cual aparece presentada y formulada a los propios miembros de aquel grupo como un sistema de valores.

Con ello se daña lo más medular de la sociedad, puesto que los valores son algo absolutamente vital para el individuo y el grupo. Ser hombre es, en definitiva, tener valores (no sólo tener intereses como el animal). $Y$ además los valores son algo intrínsecamente comunitario, cuyo ser reside en el ser-compartido, ipor eso valen! Si sólo son míos o sólo del otro, ya no parecen "valores." Normalmente la comunidad, la sociedad, elc., se generan y se sostienen por una serie de valores compartidos. En un cierto nivel de su constitución, la sociedad ha nacido efectivamente para asentarse sobre aquellos valores: los individuos que fueron constituyendo aquella sociedad o comunidad aspiraban a vivirlos. Por eso es característico del hecho social que quien no comparte los valores establecidos comienza a quedar situado como aislado o como hostil o traidor. Quien se siente solo en la valoración de un valor, comienza a sentirse separado, enemistado, etc.

Los valores son, pues, algo central en la estructuración de la convivencia humana. Lo que hemos de explicar es por qué, cuando nos encontramos con una sociedad ya estructurada, ocurre que una serie de actitudes interesadas o pecaminosas (por ejemplo, el dominio, el engaño, la absolutización de una sola forma de razón, etc.) aparecen integrados y protegidos por todo un sistema que, en principio o en su intención, es válido y valioso, por ejemplo, un sistema montado para la ayuda en la autoconservación, para el conocimiento y uso de la naturaleza, para el uso de la razón, etc. De este modo aquellas actitudes pecaminosas son casi fatalmente asumidas por el sistema valoral del cual no son más que una caricatura ilegitima. Al ser asumidas recomienzan un proceso que estamos encontrando constantemente, despiertan o encuentran resonancias en la pecaminosidad propia; y, al potenciarla se ven a su vez agravadas y corroboradas por ella. Y todo esto, sin que el individuo muchas veces acabe de percibir completamente este proceso.

El camino que ha llevado hasta ahí es enormemente complejo, pero pueden señalarse algunos de sus hitos. Los valores no son fáciles de armonizar y además exigen siempre al hombre un precio, una salida de sí. En la medida en que el valor no esté encarnado en algo concreto, quizá le sea fácil al hombre sortearlo como fantasma irreal. Pero en la medida en que el valor se implanta, se objetiva, el hombre ya no puede rehuirlo y entonces tenderá secretamente a "cobrarse ese precio" desfigurando el valor mediante una cadena constante de actuaciones interesadas, las cuales dan la adhesión a aquellos valores que for- 
man el grupo, a cambio de hacerlos incidir en la satisfacción de algún interés inmediato; o levantan un valor en contra de otro, para evitar pagar el precio que nos impone ese otro. Añádase que la necesidad (la cual quizás existe objetivamente) de defender esos valores ya establecidos, permite poner en juego una serie de medios dudosos o extremos que no se justilicarían por si mismos, pero ahora quedan justificados por el valor que dicen defender; y al ser puestos en práctica generan reflejos contrarios al valor defendido, se hace la guerra para defender la fraternidad, pero con ello el hombre se va volviendo guerrero, o vencedor, y con ello poco fraterno. El enemigo común es muchas veces quien pone en marcha y consolida ese proceso de legilimación lambién común. Por' eso es sabido hasta qué punto el "enemigo común" es factor indispensable y estructurador - y desfigurador- de tantas sociedades; insensiblemente ha pasado a sustituir al valor común.

Este proceso imperceptible de degeneración es el que convierle al valor eslablecido en excusa objetivada. Queremos subrayar, por si no ha quedado bastante claro en la descripción anterior, que este proceso no se debe exclusivamente al carácter impersonal que lo estructurado suele tener, sino que, en buena parte, arranca de procesos personales parecidos. Es sobre todo en el nivel personal donde primero actúa el hombre de esa manera. Sólo que allí, el enmascaramiento que convierte el interés en valor, quizás tiene menores márgenes de actuación: en el nivel exclusivamente personal, al hombre le costará más llamar pobreza a su mezquindad, o llamar libertad a su dominio, o llamar justicia a su venganza, o llamar obediencia a su adulación, o amor a su erotismo, o castidad a su desprecio. Puede hacerlo, pero la persona tiene ese reducto último de la conciencia que protesta contra ello, mientras que la estructura no. ${ }^{17}$ Por eso ocurre que en el nivel personal, al hombre no le queda a veces más recurso que el de sepultar ese interés en su inconsciente y dcsconocerlo. Este es - como es bien sabido- el proceso que Freud analizó. Pero cuando el hombre construye la sociedad humana ${ }^{18}$ se dan márgenes mucho mayores para que aquel interés relegado a lo que "no se quiere conocer," aflore ahora revestido de valor: la motivación 'no confesada o no conocida' pasa ahora a ser una motivación falsamente conocida y falsamente expresada. ${ }^{19}$

Esos "márgenes mayores" vienen posibilitados por una serie de factores característicos del hecho social. Por ejemplo, la imprecisión de contornos que tiene todo lo compartido, comenzando por el lenguaje; la disminución de esfuerzo que supone toda acción común, al liombre no se le pide ahora que ponga él totalmente ese nombre falso de valor, que él sólo quizás no se atreveria a poner, ese nombre lo han puesto otros, y a él sólo se le pide que lo sancione en un tanto por ciento imperceptible y minimo; mas el carácter impersonal que tiene siempre lo institucionalizado, en donde "todos" puede equivaler a "ninguno"... todos esos factores hacen que lo que - en el campo personalse llamaba el inconsciente [reudiano, o la ceguera del corazón con lenguaje bíblico, se transforme en el campo social en la "ideologia" (en el sentido marxista del término), donde lo desconocido ya no lo es por innominado, sino porque tiene el nombre cambiado, "la mentira" en lenguaje del cuarto evangelio, el cual -como ya hemos visto- es todo él un proceso (en el doble sentido de 
movimiento y de juicio) para decir a los judios, representantes de "el mundo:" están en el error, pero son culpables de su error y no meros equivocados (cf. $8,43.44$ y 9,41 etc.). ${ }^{20}$

Y cuando el hombre está inmerso en ese "mundo" ideológico, las decisiones personales ulteriores tenderán fatalmente a tomarse en el sentido de ralificación de esa ideologia o de ese inconsciente, ahora travestido. Se toman sin que el hombre parezca enterarse muchas veces de cuándo las tomó, porque no se toman repentinamente, sino en lo que podriamos llamar "la historia de identificación con una mentira." Pero ello no significa necesariamente que se tomen sin responsabilidad. De esta forma, y gracias a esta "transfiguración" del pecado al estructurarse, los hombres acaban decidiendo los valores en lugar de respetarlos; acaban dictando realmente "el bien y el mal." Bien y mal son lo que los hombres deciden desde su situación. Y aquí tenemos la diferencia entre "ser como Dios" (Gen. 3,5) y ser "a imagen y semejanza de Dios" (Gen. 1,27), lo primero es la perversión de lo segundo. En esa perversión consiste el pecado y esa perversión se implanta de mil maneras en las estructuras del convivir humano.

Por supuesto, la implantación del pecado en ninguna estructura será total y perpecua. Prescindiendo de los aspectos positivos que lo comunitario aporta al hombre (y habrá que verlo al tratar de la gracia), hay que decir que incluso la estructura pecaminosa deja siempre un margen de juego al verdadero valor, aunque sólo sea como Corma de justificación de si misma.

Todas estas consideraciones pueden parecer abstractas, pero es demasiado fácil darles rostros concretos. ${ }^{21}$ Aunque es un ejemplo que no gustará, pero precisamente porque es necesario caer en la cuenta de ello, vamos a analizar un poco lo que ocurre en nuestro mundo con el "anticomunismo." El anticomunismo puede ser un valor en sí mismo válido y legítimo. Pero en su uso esıablecido, incluye, además de un rechazo de la persecución religiosa y de la dictadura de un partido único, una serie de contenidos como éstos: una justificación tácita de la injusticia y de los privilegios propios; una negativa a todo cambio, y cerrazón a escuchar todo clamor, y una opción por la defensa del sialus quo, incluso de modo violento. ${ }^{22} \mathrm{Y}$ casi toda la gente que hace suyo el anticomunismo, o lo propaga y lo fomenta, está en realidad tragándose y alimentando esos pecados de aceptación de la injusticia existente, de negativa a escuchar el clamor de los empobrecidos y de violencia para defender los propios privilegios. Este proceso es mitad inconsciente y mitad responsable. Muchos o la mayoría de quienes participan de él, no se atreverian a pensar y actuar asi ellos solos. Pero cuando el anticomunismo se estructura como valor constituyente de una sociedad, la mentira colectiva se vuelve más fácil.

Y la lógica de esa mentira establecida puede llevar a inhumanidades increibles e inesperadas para el hombre. Puede llevar a Auschwitz, o a El Salvador, o a Guatemala, o a la pesadilla de los desaparecidos, a los refinamientos increibles en la tortura, y hasta al silencio complice de las iglesias. Y sin embargo, a pesar de esos frutos, iqué dificil es abolir esa mentira estructurada del seno de nuestro mundo occidental! 
$\mathrm{Y}$ aunque sé que los ejemplos son molestos, permítaseme todavía otro, porque creo que son necesarios. Es muy posible que el argumento de quienes defienden la carrera de armamentos sea válido, es decir, que ya no hay otra posibilidad para una defensa que, por otro lado, es legítima. Pero es cierto que ese argumenio, una vez aceptado, engendra o da entrada a una serie de pecados, como el dinero desviado de los pobres a las armas, la necesidad de "armarse mejor" en que se pone a los paises pobres ( $y$ que en realidad es necesidad de deshacernos nosotros lucrativamente de aquellas armas que ya no nos sirven), despojándolos de sus propios recursos para darse esas armas; la "adicción" a los formidables beneficios que el negocio de las armas produce; la valoración lácita de la agresividad y de la violencia que la carrera armamentista acaba potenciando. Sobre este último punto habría que subrayar que no es sólo la violencia ya ejercida quien engendra violencia; es también la violencia preparada o la agresividad, la que engendra otro modo de ser violento. ${ }^{23}$

Esta es nuestra situación sin salida. El pecado engendra pecado o produce muerte. Discutir si de este pecado estructurado somos autores o victimas, es una discusión tan inútil como la de los galgos y los podencos, cuando lo único urgente es disculir cómo se puede romper ese círculo de muerte. La otra es una discusión que no aspira a salvar del pecado, sino a salvar el amor propio.

Igualmente es posible encontrar católicos que nunca se permitirian, ni como hombres ni como creyentes, conduclas que se han permitido porque eran "en defensa de la fe." El rosario de ejemplos lo tiene cada cual en la sociedad nuesira de cada dia. El pecado se estructura como ideología y como mentira social, aunque, por supuesto, la sociedad no es sólo pecado estructurado. Pero

"se comprende que una civilización, aunque penetra la mentalidad de todos y cada uno, no lo haga sin que se participe algo en la responsabilidad de su acogida." 24

\subsubsection{La seducción implantada o el escándalo}

La reflexión del presente apartado podría ser considerada como ampliación de un pequeño lragmento del tapiz anterior: una intensificación de lo que alli expusimos, pero donde aparecen algunos mecanismos nuevos porque el examen está hecho ahora a niveles de infiujo más reducidos, por ser más personalizados. Vamos a entrar en esta reflexión evocando las llamativas palabras de Jesús sobre el escándalo (Mt. 18,7).

Son de sobra conocidas tanto las palabras de Jesús como la sorprendente intensidad o dramatismo que posee. Se aceptará también, como dato escueto, que la reflexión teológica sobre el hombre no ha sabido integrar demasiado esa intensidad de las palabras de Jesús: más bien tendemos a pensar que - salvo algunos casos aislados - son exagerados. Por eso las palabras de Jesús sobre el escándalo - al igual que el concepto joánico de pecado del mundo- han quedado olvidadas en algún lugar del desván de nuestros recuerdos. A lo sumo, algunos moralistas victorianos las utilizaron para tronar contra "la inmodestia en el vestir" y otras calamidades semejantes, que no sabe uno si tendrán demasiada relación con la angustia del Nazareno. Jesús parece considerar al 
escándalo como algo inevitable ("es necesario que ocurran") pero, a la vez como algo nefasto ("ay del mundo por ellos"). De ahi su tragedia. La inevitabilidad del escándalo brota de pertenecer a la estructura misma de la convivencia; y su fatalidad proviene de que la destroza. Por lo tanto, podemos decir que el escándalo es otra forma de pecado estructurado.

Para entender su necesidad hemos de saber que el ejemplo, o la oferta de vida de otros, es siempre una pieza constirutiva de mi propia realización. Cuando esa "pieza" está rota (cuando el testimonio es "escándalo" o el ejemplo es mal ejemplo) todo mi ser está impedido o en dificultades serias para su propia realización.

Conviene insistir, para no ser malentendidos, en el carácter "inırínseco" que tienen determinados datos del existir humano que consideramos como meros factores extrínsecos. Cada ser humano no es una isla, ni un castillo ni una "monada," sino una "estación," un núcleo de relaciones. Sólo llega a "estar consigo," a poseerse e identificarse consigo mismo, sólo llega a la autoconciencia a través de la mediación de lo exterior, aunque la autoconciencia pueda funcionar después como olvido de lo exterior. Por eso hay siempre una "verdad" interior al hombre que está todavia fuera de él, en todo eso que llamamos la ley, o el valor, o el "tú," etc. Y esa relerencia exterior es sobre todo una referencia a los demás hombres: el yo nunca puede ser real y plenamente tal, sino en el seno de un nosotros. La capacidad de influjo que los demás tienen sobre nosotros no es algo ni irrelevante ni contingente. Y ahora me refiero a los demás no a través de mediaciones estructuradas, sino en cuanto personas particulares. El hombre necesita normalmente, aun para su pura salud psíquica, que los otros aprueben su conducta y sus opciones, sobre todo cuando éstas son costosas. Vive buscando esa aprobación aun sin darse cuenta, como vive buscando el aire sin notarlo. Y "morir" en la pura desaprobación, en la pura y total soledad como Jesús, aun cuando no se trate de la muerle fisica, es de lo más duro e incomprensible que hay; siempre resuena sobre esa muerte el grito del brasileño Rubem Alves: “¿Por qué el rechazo cuando todos hablan de adaptarse? ¿Por qué negar cuardo todos afirman? ¿Por qué ser libre para el futuro cuando todos se encuentran domesticados en el presente?" 25

$Y$ esta referencia intrínseca al otro no se maniliesta sólo en que el hombre necesita de los demás para tener madre, o médico, o lampista o consejero Sino todavia más, se manifiesta en que cada vida particular, y el conjunto de todas las vidas son para los dernás un testimonio, el cual no es mero testimonio, sino invitación, interpelación y demostración. ¿Por qué? Al responder a eso estamos ya en lo nocivo del escándalo.

El hombre es un ser siempre necesitado de educación, porque su configuración contradictoria (instinto-razón, materia-espíritu, individuo-comunidad, creatura-sobrenatural...) lo convierte en "un dato caótico que exige una integración." 26 Ante este dato, toda otra vida o testimonio vital, al menos algunos de ellos según personas, educa o des-educa, es decir, influye en que esa integración exigida por todo hombre sea una integración por medio del amor, iel único que puede realizarla! o sea una integración falsa o inconsistente. 
En efecto, ante la "necesidad de incegración" que cada hombre es, la vida del olro se convierte en una oferta de solución: "a mi me va bien así," éste es el camino. $\mathrm{Y}$ el hecho de que el orro diga que a él le va bien asi, convierte la ofrenda en demostración, como quien ofrece un medicamento que a él le salvó la vida. Ahora bien, infinidad de veces, cl hombre que hace esa oferta vital no la da como testimonio desinteresado y cn el cual a él no le va nada, sino buscando en ella, a su vez, la aprobación del olro que él lambién necesira. Si uno necesita de la aprobación o refrendo del ouro para decidirse a actuar de una determinada manera, quien ya está actuando asi, necesita también de ese refrendo, y trata de encontrarlo imponiendo st: acruación y buscando seguimiento. Por eso, no existe en la sociedad humana conducta desviada que se limite a exigir sólo el respeto a la liberıad de toda conciencia y a la soledad de toda libertad, lodas las conductas acaban aspirando a la sanción social y buscándola como sea. La libertad de conciencia sc convierte siempre en proselitismo. Y en esta curiosa esiructura de la relación humana es donde sc implanta el escándalo.

El escándalo no es, pucs, algo que aparece contingemtemente, como fruto de una voluntad expresa de perverlir, o como una mancha en el vestido que podría no haber aparecido. Sino que todo ser humano es para los demás (o para algunos de ellos) escándalo o camino. Toda vida humana configura algo de la bondad o maldad de otros, y es configurada en su bondad o maldad por la vida de olros. A esto se le suele llamar "estar situado." 27 Pero debemos insistir en que esa situación no es algo meramente extrínseco que puede no tenerlo el hombre, sino que sólo se puede ser hombre eslando siluado. Por eso, una situación pecaminosa o mala, malea efectivamente al hombre. Esto es el escándalo. $Y$ desde ahi podemos afirmar que el pecado estructural no es algo extrinseco que puede no lener el hombre, en quien sólo su culpa personal sería algo intrinseco, sino que es como cl aire que está a la vez dentro y fuera de mi, en una interacción imperceptible y constante.

\subsubsection{La imposibilidad implantada o el pecado como falsa necesidad}

Otra de las formas como se implanta estructuralmente el mal es haciéndose no sólo valioso y tentador, sino necesario. Jacinto Benavente pintó con lucidez esa trama humana de los "intereses creados." En realidad, los intereses creados son sólo el primer paso de una trama sutil que lleva aún más lejos, hasta las "necesidades creadas." Esta es la manera más eficaz de implantación del mal y la que más completamente lo enmascara. Y esta implantación tiene abierta su puerta en el hecho de que el hombre es un ser de necesidades; en la medida, pues, en que el mal se entremezcla y se lunde con la necesidad humana y con su tremeda ruerza biológica, se puede convertir casi en naturaleza del hombre.

Y este proceso es aún más posible por cuanto eso que llamamos "la naturaleza del hombre" es una dimensión elástica y abierta, que no puede circunscribirse sólo por sí misma, prescindiendo de la historia y de la cultura y de los demás hombres. Así, por ejemplo, es lácil distinguir en teoria entre la necesidad legítima y el egoísmo ilegitimo; pero lodo el mundo sabe lo difícil que es 
precisar en la práctica y de manera definitiva los límites cuya transgresión lleva de la una al otro. Todo el mundo constata también que el hombre tiene aqui dos medidas y ve las cosas de modos muy diferentes, según se trate de sí mismo o de los otros, la subjelividad tiene razones que una presunta "razón objetiva" desconoce.

A pesar de estas dificultades de delimitación, todo el mundo ha podido palpar también, en algún momento, la existencia de necesidades falsas y cómo actúan en nosotros. Por evocar un ejemplo muy trivial, piénsese en el caso de muchos fumadores crónicos. Hay personas a quienes según dictamen médico repetido, el rabaco las está destrozando y a cambio de esa amenaza no obtienen en realidad ninguna satisfacción verdadera. Para ellos el fumar se ha convertido en una pulsión mecánica y nerviosa, en la cual no se saborea en realidad nada, pero de la cual no pueden prescindir, a pesar de que sus desventajas son ya infinitamente mayores que sus hipotéticas ventajas. Si no fuman están más nerviosos y esto es cierto, aunque no debería serlo.

De manera parecida, también el mal moral puede implantarse como falsa necesidad. Esto es lo que quería decir la clásica teoria moral de los hábitos. Pero aqui afirmamos además que puede implantarse no sólo en casos o personas particulares, sino en los niveles que estructuran la sociedad humana y la humanidad entera. Con la diferencia de que el fumador de nuestro ejemplo anterior podrá quizás reconstruir con la memoria el proceso de las pequeñas decisiones que lo fueron esclavizando; mientras que - socialmente hablando- es del 10do posible estimular el deseo, o potenciar el uso, o sugerir una falsa promesa, sin que estos procesos sean vividos por el hombre como responsables, ya que han nacido de la matriz. misma donde todo hombre está implantado para ser hombre, la matriz social.

En este caso, pues, la necesidad del mal no sólo enmascara su carácter pecaminoso, sino que lo presenta prácticamente como "querido por Dios" y empuja a aceptarlo como bueno. Una determinada manera de estructurar, por ejemplo, las relaciones económicas de producción y distribución de bienes, en la cual el valor "capical" o el valor "producción" o el valor "beneficio" estén por encima del valor "hombre," ha convertido en absolutamente necesarias a toda una cadena de injusticias que ya no son calificadas como injustas, sino como "leyes de la economía." Los gestores de esas estructuras preferirán pensar entonces que tales leyes son inmutables, y al mencs si será verdad que no dependen de ellos solos, para poder seguir aplicándolas. No quieren preguntarse si no estará enferma una sociedad cuyas leyes implican fatalmente injusticia y hambre. Y en cambio, esto es lo primero que se preguntarian si, en lugar de tratarse de salarios insuficientes o de accidentes laborales (ique no afectarán a los gestores de las estructuras!), se tratase del cáncer o del infarto. Una sociedad donde el porcentaje de cancerosos fuese tan alto como el porcentaje de parados sería una auténtica alarma sanitaria y crearia una imparable neurosis colectiva. ¿Por qué esa diferencia? Porque el cáncer es más evitable que la pobreza. No, sino porque, en el caso del cáncer o del infarto, se trata de males que amenazan indiscriminadamente a todos, mientras que en el otro caso no. Y cuando la amenaza es personal, entonces la protesta innata del dolor fisico 
se vuelve inacallable. Mientras que la otra protesta del dolor moral (la protesta de la solidaridad y de la conciencia) es más fácilmente eliminable. Por eso nadie dice que la producción de infartos o cánceres pertenece a las "leyes de la medicina" y que son algo natural y "querido por Dios," sino que más bien se busca qué es aquello que falla en la estructuración de la vida humana y que lleva a producir tales enfermedades. Aqui no se piensa sólo en remedios, sino en medicinas preventivas. Allá no se piensa ni siquiera en los remedios.

Pero el proceso de implantación del pecado como necesidad no termina ahi. Aún hay un último paso trágico que debemos señalar, la "Talsa necesidad" que esclaviza a algunos engendra necesariamente las necesidades, muy reales, pero "desesperadas," de otros muchos, quienes como saben que sólo van a poder repartirse unas migajas completamente insuficientes, se vuelven a su vez enemigos e insolidarios entre ellos. ${ }^{28} \mathrm{La}$ mayor implantación del mal no es el crear falsas necesidades de consumo, sino el colocar a los hombres en situaciones donde sea necesario hacer el mal, donde no se pueda practicar el bien ni creer rectamente. Obligar a robar a matar, a drogarse, a prostituirse, a declarar el estado de excepción... Nadie puede medir si había tal necesidad, pero al menos el impulso social a ella puede ser enorme. Y luego, quien haya sido obligado a esa conducta se sabrá excomulgado, rechazado, no aceptado, quizás se condenará él también a si mismo, y, al sentirse excluido, no se acercará ya a la comunidad de los hombres "honrados"...

Así, pues, y de acuerdo con cuanto llevamos dicho, el pecado estructural se podría comparar a una adicción, a un "hábito," de carácter no personal, sino social. Un hábito adquirido o impuesto; pero, en cualquier caso, es el organismo social el que está intoxicado y es adicto. Y el organismo social es algo más que la suma de los individuos, es la red de relaciones establecidas que los unen ya antes de sus relaciones personales.

Ahora bien, si en el caso del hábito personal, el trauma de la supresión del "veneno" es casi imposible de superar, mucho más insuperable e incontrolable lo es en el caso de la adición social. Las "contraindicaciones" y las reacciones del organismo social son infinitamente mayores, y un solo individuo no puede manejarlas. Ello hace prácticamente imposible eliminar la adicción. Sólo queda pactar con ella. El cambio no ya violento, sino inevitablemente brusco de estructuras se verá impedido porque los miembros "drogados" o afeclados de la sociedad reaccionan con una violencia desesperada, convencidos de que aquel trauma es una agresión a su misma naturaleza. Esto no es cierto, pero es que ellos han acabado confundiendo su vicio con su naturaleza. De ahí que con tanta convicción puedan esgrimir argumentos de "derechos humanos" y predicar cruzadas contra aquello que no apuntaba en realidad suprimirlos a ellos, sino a suprimir la objetivación de su pecado. $Y$ es de sobra sabido además, cómo esas resistencias consiguen a su vez. violentar y radicalizar la acción transformadora, llevándola a convertirse muchas veces en una verdadera agresión ya no justificable, aunque quizás inevitable. Con ello, la acción transformadora podrá ser desautorizada, y el pecado implantado obtiene su mayor victoria. 
¿Es preciso concretar aún más cuanto estamos queriendo decir? La humanidad dispone hoy de recursos impresionantes (económicos, psiquicos, intelectuales...) para buscar la paz con la naturaleza y la comunión entre los hombres. En lugar de destinarlos a eso, la actual humanidad dedica una cifra aplastante de sus recursos a estas dos cosas: a preparar la guerra entre los hombres, armamentos y "defensa," y a buscar el dominio aplastante de unos hombres sobre otros para permitir el lujo sofisticado de unos pocos al margen de la necesidad estremecedora de la mayoria. Existe champú para perros o escuelas para perros, alli donde la mitad de los niños tienen piojos o no tienen escuela. Se importan cosméticos de París allí donde no hay suficientes vacunas contra la poliomelitis... Y todas esas cosas se reclaman como primarias, y con una agresividad tal que la privación de ellas es vivida como una auténtica agresión, capaz de justificar incluso una guerra civil en supuesta "legítima" defensa...

De hecho, el hombre sabe ya prácticamente todo sobre cómo destruir la tierra y a los hombres. Y lo sabe no sólo teóricamente, sino que lo tiene preparado prácticamente. Esta es la primera, y hasta hoy la única, asignatura que el género humano ha terminado y aprobado con matrícula. Una asignatura que, por lo demás, no entraba en el programa de su carrera humana. En cambio, el hombre sabe todavia poquísimo respecto a cómo remediar el hambre o cómo prevenir los terremotos o cómo evitar las amenazas de sus propios progresos... Las necesidades creadas invierten las prioridades de los valores y refuerzan asi el primero de los puntos de nuestro análisis.

Y este estado de cosas no es, hoy por hoy, superable. Viene de lejos, se ha ido acumulando en una historia progresiva de olvidos, de insolidaridades y de antifraternidad. La buena voluntad de una hipotética conversión actual se revelaría inútil para remediarlo con prontitud, porque chocaría con faltas de "fundamentos" que no se ponen en un dia; habria que "repetir curso," como se dice a los niños cuando no pueden suplir estudiando a última hora lo que se apoya y depende de cosas que deberían saber desde mucho tiempo antes. Pero al dar este consejo se constala que habría que repetir también el curso anterior, y el otro. Habria que repetir toda la carrera humana. Por eso, el pecado estructural - como el personal- nunca pueden eliminarse del todo. Pueden quizás contenerse, rebajarse. Y sin duda seguirá siendo posible entonces poner infinidad de remiendos y conseguir infinidad de victorias parciales. Pero ninguna de ellas constituirá el remedio total y otras serán pervertidas a su vez por el sistema mismo. Porque el pecado estructural no es fruto de un determinado sistema de sociedad, sino del sistema humano mismo: del mundo. El hombre luchará siempre en condiciones de inferioridad contra un enemigo superior a él: el pecado del mundo o pecado estructural, el cual se escapa de sus manos aunque, en parte al menos, sea obra de sus manos.

Y si alguien considera que estas son palabras demasiado pesimistas y que amenazan con devolver al cristianismo a aquella trágica resignación de antaño, habría que responder que no se trata de pesimismo, sino más bien de seriedad. El pecado estructural no implica alirmar que en este mundo no pueden existir la justicia, el amor y la libertad, sino que sólo pueden existir con la amenaza de 
ser crucificados, porque el mundo está montado y funciona sobre la injusticia, el desprecio y la opresión, iy de otro modo no funciona! (como el drogadicto); y el mundo no quiere adernás cambiar ese status. Quien busque la Justicia, el Amor y la Libertad no crucificadas caerá en la Calsa justicia, el amor falseado y la pseudolibertad del sistema. Quien los busque auténticos, el pecado estructural no le predicará una resignación que sólo dice "no los encontrará," sino un coraje que dice, "los encontrarás crucificados." Esta es la relación entre pecado estructural y cruz de Jesús.

\subsection{Balance: pecado estructural y enmascaramiento}

Al término de estos breves análisis sobre la ideología, el escándalo o "las necesidades creadas," aparece una de las características más graves del pecado estructural: al estructurarse, el pecado se impersonaliza y así se enmascara más fácilmente. El usurero de antaño es un personaje abominable. Y mientras los usureros eran personas concretas la Iglesia los anatematizó constantemente y severamente. Pero, cuando el usurero se convirtió en un "banco," perdió su rostro de pecador y hasta se transformó en institución social benéfica. No importa luego que las tasas de interés sean injustas y espeluznantes, ni que los bancos sean casi la única entidad que, en medio de todas las crisis económicas, sigue arrojando unas cifras de beneficios literalmente obscenas, ni que la diferencia entre los intereses que el banco da y los que exige resulte casi sórdida, ni que no puede caber en ninguna razón el que esa ficción abstracta del dinero sea claramente más rentable que el trabajo y el esfuerzo inteligente, ni que el banco, que se presenta sólo como un servicio estructurado para todos, sepa luego muy bien con quiénes se trata, y exija, por ejemplo, unas garantias tales que lo reducen a ser sólo un servicio "para los leones" que menos necesitan... A pesar de todo eso, el rostro personal del usurero ha desaparecido y, con él, la usura. Con la anonimidad y la impersonalidad, todo lo anterior se enmascara, y el banco acaba por aparecer sólo como una sencilla cooperativa donde todo funciona en beneficio de todos y nadie se aprovecha para esquilmar a otros. La antifraternidad estructurada puede incluso llamarse servicio público. Así se ha llegado a producir una buena parte de la llamada "deuda" de los paises del tercer mundo, la cual en esa "buena parte" no es deuda, sino atraco enmascarado. Y se produce también el que aquéllos que están llamados a ser la conciencia de la humanidad no se hayan atrevido a denunciar y resistir a ese atraco. La denuncia y la resistencia sólo han venido de los enemigos de nuestro bloque político quienes, como obedecen a otros intereses igualmente estructurados, aparecen por eso mismo como sospechosos. 29

\section{APENDICE}

\section{Pecado estructural y crítica de la sociedad}

Todo lo dicho nos introduce a un tema del cuál ninguna reflexión sobre el hombre puede ya prescindir: el de la decepción del hombre por todas sus obras. Es el tema de aquel famoso y lejano "no es esto, no es esto" con que los 
intelectuales españoles iban saludando y distanciándose a la vez de la República que ellos habían contribuido a forjar. El tema de la desilusión de toda la izquierda europea ante la revolución rusa. Se puede decir tambièn que ese mismo tema es el de la desilusión de muchos cristianos por el Vaticano II, en cuanto que es innegable que hubo quienes tomaron el asombroso soplo del espíritu que conmovió a la Iglesia de entonces, como una simple "excusa para el egoísmo" (Gal. 5,1). Aunque, a mi juicio, tienen razón quienes afirman que son muchos más los bienes que el Vaticano II ha aportado a la Iglesia; y que los males que parecen haber provenido de él, no eran antes inexistentes, sino que estaban sólo reprimidos, acumulados y negados oficialmente. Pero no es este momento de discutir esa cuestión. La lista de ejemplos sería inacabable.

Pero el ejemplo más global y más paradigmático de ese extraño potencial de decepción con el cual las obras del hombre acaban pagando a su autor, y juzgándole con ello, lo constituye hoy toda la corriente filosófica que suele llamarse "teoría crítica de la sociedad," la cual ha inaugurado una reflexión perpleja sobre la modernidad, en la cual laten secularizados infinidad de lamentos teológicos. ¿Cómo es que todo un mundo que quiso expresamente ser edificado sobre la razón y sobre la libertad, ha terminado produciendo más sinrazón y menos libertad? He aquí una cuestión que hoy ya no puede rehuir la humanidad. 30

Más sinrazón porque irracional es la existencia de una pavorosa amenaza atómica, la cual no puede desaparecer porque sirve para proteger a la sociedad que la produce y para domesticar el terror que ella misma provoca.

Menos libertad porque esa sociedad no sirve para liberar de las necesidades humanas, sino para satisfacerlas artificialmente, "sintéticamente" y, a la vez, tantálicamente, con objeto de que la necesidad perdure y pueda ser manejada.

Más sinrazón, porque la capacidad cada vez mayor de producir más, va acompañada de la incapacidad cada vez mayor de repartir mejor.

Menos libertad porque esa sociedad cerrada tiene una descomunal capacidad de integración de todas las oposiciones, por feroces que parezcan ser, hasta convertirlas en beneficio propio. Y origina asi una falta radical de verdaderos agentes de cambio.

Más sinrazón porque esa sociedad sólo ha servido para sustituir la amenaza mítica de la naturaleza, por la amenaza anónima del todo socio-técnico que ha servido para dominarla. Con lo que se ha pasado del dominio de la naturaleza sobre el hombre, al dominio de las obras del hombre sobre el hombre.

Menos libertad, porque esa sociedad ha venido a ser una pura "sociedad de funciones," donde ser equivale sólo a ser-medio-para-algo, donde el individuo no tiene identidad y sólo puede subsistir a costa de ese no-tener. Menos libertad porque esa sociedad de intercambio reduce todos los individuos a "equivalentes" y no deja más salida que cl adaptarse para sobrevivir.

Más sinrazón porque la máxima expresión del espiritu y de la razón humana: la cultura, se ha convertido ahora en una "industria" que domestica a las 
masas, presentando la presión social como inevitable y como llena de sentido, y se convierte así en el gran negocio y en el gran aliado del "todo"...

Menos libertad porque entonces el todo social se hipostatiza contra los individuos que lo componen, y que le deben la vida a cambio de ser impotentes frente a él.

La pregunta sobre el porqué de toda esta metamorfosis de Prometeo en Sísifo, no ha sido una pregunta inútil, puesto que ha detectado errores y pecados estructurales del proceso, que podríamos formular así: en los orígenes mismos de la civilización moderna están latentes un principio de dominio y un principio de engaño, que pueden dar razón de muchas de sus degeneraciones posteriores. El principio de dominio proviene de una sacralización de la lógica de la autoconservación (sacralización que los hombres tenderán fatalmente a hacer cuando todo lo tienen en esta vida y sólo en ella). El principio de engaño proviene de una secularización de la lógica religiosa del sacrificio, con la que el hombre intentaba en realidad "engañar" al dios y manejarlo a su antojo.31

Si todo esto es así, no es extraño que se haya podido escribir que fenómenos como Auschwitz no son un accidente, sino un resultado de la historia de la civilización occidental y la primera vez que eso se escribió tenía uno derecho a considerarlo como una exageración; pero cuando tantos Auschwitzs se repiten, a pesar de los horrorizamientos y de los buenos propósitos, es legítimo pensar que quizás haya algo de verdad en la afirmación. Tampoco será extraño que se haya podido escribir que la bendición del progreso constante es la maldición de la incesante regresión. O que la sociedad occidental lleva insita una brutal lógica de autodestrucción. Ni será extraño por último que el "gran rechazo," el no radical que acompañó a la toma de conciencia de todo esto durante ef linal de los sesenta, se haya convertido hoy en la estremecedora domesticación por el todo social, de unos hombres que están sufriendo de él mucho más de lo que tuvieron que sufrir sus hermanos mayores de dos décadas antes.

Quizás podrá discutirse la afirmación de T. Adorno y M. Horkheimer que descubren esa falsificación de la "Ilustración" ya en los albores mismos de occidente: en la manera como la Odisea interpreta los mitos griegos. El "ilustrado," el astuto Ulises se enf renta con toda una serie de amenazas: Circe (el mito de la sexualidad), Polifemo (mito de la naturaleza), las Sirenas (mito del descanso) o los Lotófagos (mito de la droga), y siempre saca de todas ellas la ventaja sin desventaja. Muerde el cebo de sus ofertas sin caer en la amenaza de sus redes. Pero de hecho saca esas ventajas a costa del engaño, a costa del sacrificio y la opresión de otros hombres que trabajan para él y no tienen más remedio que hacerlo, y a costa también de un desproporcionado precio propio pagado en forma de dolor, heridas, retraso, cansancio, etc. Concedamos que quizás puede discutirse este análisis. Pero ambos principios - de dominio y de engaño- tienen demasiado peso como para que podamos pasar por alto tranquilamente su constatación por los analistas de la sociedad.

Ambos principios desembocan inmediatamente en un mismo criterio de actuación. La razón en occidente no ha sido un medio para hacer al mundo más "razonable," sino para hacerlo más racionalizado. No ha sido un medio 
para hacer más humano al mundo, sino el instrumento decisivo para hacer más calculado el dominio y más perfecto el engaño. Eso es lo que se llama "razón instrumental." El mundo edificado sobre ella ha de ser necesariamente un mundo irracional e inhumano, por cuanto el hombre no es simplemente un instrumento. Y no se atenta impunemente contra lo humano. Pero ese mundo inhumano, no se percibe a sí mismo como tal porque sólo se mide con la escala valoral de esa razón instrumental. El resultado de esa falta de percepción es doble; por un lado, la vida se va volviendo cruel, brutal, atroz, para la gran mayoría de los hombres, y éstos a su vez - porque quieren escapar a esa vida o porque son víctimas de elia - se vuelven ellos mismos crueles para los demás. Pero, por otro lado, luego nadie quiere salir de ese mundo atroz, porque no estamos dispuestos a pagar los precios de moderación del deseo y aceptación de la verdad, los cuales serían precisos para intentarlo. Así, la sociedad moderna se va asemejando cada vez más a un mundo en el cual sólo viviesen diabéticos, y en el cual sólo se produjeran dulces: en sus formas más variadas, exquisitas y refinadas, pero sólo dulces. El hombre de ese mundo se vería abocado a este dilema, o morirse de hambre para salvar su vida de un coma diabético fulminante, o entregarse en cuerpo y alma a esa totalidad social que, con una mano, le suministraria alimentos y le evitaria morir de hambre a precio de agravar desesperadamente su enfermedad, y, con la otra mano, le suministraria en sus modernas clínicas insulina abundante y tratamiento para la enfermedad que esa totalidad le provocaba y mantenía. Y ese mundo sigue adelante, sofisticando sus dulces y aumentando sus investigaciones médicas, pero sin abordar ni en sueños la hipótesis de un cambio radical de su producción. Y por lo general cuenta para eso con el apoyo de la mayoría de los diabéticos, quienes son unos golosos empedernidos. Algo así es el pecado estructural.

Y una última observación para cerrar este breve apéndice. Al evocarlo no hemos querido afirmar que todo el pecado estructural sea el capitalismo solo, o solo occidente. Como tampoco prentendemos que muchas de las afirmaciones hechas tengan sentido exclusivo, como si la modernidad fuera sólo eso, en lugar de ser un proyecto más amplio y más positivo, que está larvado por todo eso. Tampoco era esa la pretensión de los autores de la Escuela de Frankfurt quienes iniciaron la filosofia critica de la sociedad. Nosotros hemos pretendido presentar, a quienes viven tranquilos en "el mundo" y prefieren desconocer su pecado, unos ejemplos de presencia del pecado estructural. El lector occidental y moderno tenderá a preguntar indignado por qué no hemos mostrado el pecado estructural de los países socialistas o de los paises del tercer mundo. La respuesta es bien sencilla, los lectores ( $y$ el autor) de este artículo serán casi todos del primer mundo o de un tercer mundo dominado por el primero. No debemos caer en el pecado de mirar la paja en el ojo ajeno cuando quizás tengamos que quitar antes una viga del propio. Nos obliga a eso no sólo una elemental honradez, sino el hecho de que occidente ejerce un innegable dominio sobre la configuración de todos los demás mundos. Dominios tecnológico, económico, político y cultural. El más pobre campesino de un poblado atrasadísimo del valle del Nilo puede ver hoy por televisión telefilmes norteamericanos donde asimila la visión estadounidense del mundo y sus valores, quizás contrarios a los propios, y absolutamente irrealizables en su mundo 
concreto. Y cuando se ha protestado con razón contra el imperialismo cultural que a veces ha ejercido el afán misionero de la Iglesia, no se puede transigir tranquilamente con el imperialismo ejercido por el a án misionero (o quien sabe si sólo lucrativo) del progreso. ${ }^{32}$

La misma observacion vale respecto de la Iglesia. También en elle cabe el pecado estructural aunque no sea éste el momento de analizarla. Precisamente por eso es necesaria la crílica en ella, aunque esto no signifique que lodas las críticas sean ya acertadas por el solo hecho de ser criticas. Negar esta necesidad amparándose en el amor que se le debe, es caer otra vez en el pecado de enmascaramiento, el cual implícitamente negaría el que la Iglesia está formada por hombres pecadores, y acabaría en el culto solapado a las personas.

\section{NOTAS}

1. He aqui olras formulaciones: "Lo que menos me preocupa en el mundo es la suerte de los demás; no tengo la minima fe en la fraternidad, de la que los estúpidos me hablan continuamente. Es por haberla analizado bien por lo que yo la rechazo"... "El pretendido hilo de frarernidad que debe unir a los hombres sólo puede ser imaginado por el débil, pues no es natural que el fuerte que no tiene necesidad de nada, haya podido dar existencia a esa fraternidad. Para avasallar al débil no necesitaba más que la fuerza. La fraternidad es, pues, obra del débil y sólo esıá fundamentada en una argumentación tan esıúpida como la del asno que dijera al lobo: 'no debes comerme porque yo iengo cualro patas como lú'..." "Que la religión de ese tunante Jesús, débil, languideciente, perseguido, singularmente interesado en dominar a los tiranos y ganarlos para sus principios de fraternidad que le aseguraban tranquilidad, haya sancionado estos vinculos, es cosa que se comprende sin esfuerzo." Subrayados mios.

2. Por eso tales personajes, como el Norceuil de Juliette, se entenderian mejor en mi opinión si pensamos que en ellos habla no un ser humano, sino un "mundo," un sistema, una cultura o, al menos, una clase social. Asi nos acercamos al tema del pecado esiructural.

3. $Y$, por supuesto, tradúzcase esa frase a los diferentes universos culturales.

4. Y repito lo que insinuaba la nola anterior, en estos momentos de nuesira exposición da lo mismo que a ese mal 'estructurado' se lo conciba como el ancicomunismo que inspira tales conductas, o como el comunismo que las provoca o - lo que seria más realista y más sensato- como ambos a la vez.

5. Lo mismo pasa con el aspecto histórico del pecado, que no podemos analizar ahora. Las grandes decisiones pecaminosas no las Ioma el hombre pasando, por asi decirlo, de cero a menos cien, sino a través de un proceso insensible de acercamiento. Cuando Estados Unidos decide pur ejemplo intervenir en Vietnam no pretende echar bombas de napalm. A eso se va llegando insensiblemente, a lo largo de la guerra, si bien es cierı que tambièn en ésta se está aún a tiempo de volver atrás.

6. La palabra aramea que podria estar subyacente significaria a la vez cordero y siervo. Y la alusión a Is. 53 que parece contener la frase haría preferible la scgunda versión.

7. C.. J. Mareos, El evangelio de Juan, Madrid, 1979. p. 1040.

8. Ibid., pp. 1041-1042. La cita dice expresamente: un sistema opresor "basado en el dinero." Aspecto éste del que ahora podemos prescindir por razones de cautela exegética.

9. Cf. X. Alegre. "Mi reino no es de este mundo (Jn. 18,36)," en Estudios Eclesiósticos 54 (1979) 499-525. El artículo lleva un subtítulo expresivo: "Connictividad de la existencia cristiana en el mundo según el cuarıo evangelio."

10. Esto parece significar que el verdadero núcleo teológico de la cuestión de Salán consiste en dilucidar esta relación entre pecado estructural y principe de este mundo; aunque este cs uno de los aspecios que menos se ha considerado al plantear y disculir la pregunta por la existencia del demonio.

11. Los subrayados son siempre mios.

12. Hemos de prescindir ahora de las posibilidades que ahi se encierran para una auténtica redención de la mariología. El fiat de Maria es precisamente lo contrario del sometimiento al pecado o a las estructuras de pecado, del mundo. 
13. Y este es para Puebla "un proceso permanente" (28I).

14. Por eso no puede decirse que el pecado del mundo sea sólo el conjunto de los pecados personales de los hombres, como parecen insinuer M. Flich y Z. Alszeghy: con il 'peccato del mondo, ciod con l'insieme dei peccali personali di Iurti gli uomini (Cr. Gregorianum 47, 1966, p; 203). En cambio, en ese desbordamiento del hombre por sus obras se puede insinuar otra vez el sentido teológico del "príncipe de este mundo."

15. Merece la pena discutir hasla qué punto ese tópico es fiel reflejo del pensamiento de Rousseau.

16. Es, a mi modo de ver, muy expresiva la manera como formula J. Nabert la corrupción de la idea de patria: "un nosotros que debería servir para liberar al yo" se convierte en "un nosolros que sirve para afirmar al yo" (Essai sur le Mal, p. 109).

17. Cuando la estructura no es sólo estructura, sino un nivel profundo comunitario, tampoco será muy posible esa falsificación, pues la comunidad es comunicación de conciencias.

18. "Cuando" no tiene aqul un sentido temporal, como si fuese posible conocer primero al hombre solo y luego en sociedad. Se trata de una absiracción puramente conceptual, que intenta mirar por separado los aspectos más personales y más sociales del proceder humano.

19. En este sentido puede decirse que Freud revaloriza la doctrina tradicional de la ascética sobre "la intención recta" (que quizés se habia degradado en una especie de "canto a la ineficacia'...) ¿Quién puede saber por qué actúa realmente no sólo al conservador que deliende, sino también el revolucionario que cambia? Por eso vale la parodia paulina que hemos hecho en otras ocasiones, si yo hago la revolución y no tengo amor... no me sirve de nada.

20. Quizass valga la pena subrayar que no se trata sólo del cuarto evangelio, aunque éste haya acuhado la noción tan útil de pecado del mundo, que ya analizamos. Pero creo que es por demb́s exacto (pese a su globalidad) el siguiente comentario: "La Biblia está toda centrada sobre la culpabilidad de falsas sabidurias, de idulatrías, de desconocimiento del sentido del mundo, y de la inversión de los fines de la comunidad humana; sobre culpabilidades que no brotan de las fuerzas oscuras del instinto, sino de solidaridades sociales y de mentalidades colectivas" (Paul Guilluy, "Sciences humaines et péché de l'humanité." En la obra de AA.VV., La culpabilité fondamentale. Péche originel et anthropologie moderne. Duculot, Lille, 1975, p. 170).

21. Otras muchas cosas quedan por analizar. Por ejemplo, el diferente papel de los hombres en esa estructuración del pecado y, en concreto, el papel de personalidades con más dotes y más ejercicio de liderazgo. Pero hemos de limitarnos a aquello que más direciamente atafie a nuestro objetivo teológico.

22. Esta misma me parece ser la ensenanza (cuidosamente sepultada) de Medellin y Puebla. Los sectores más favorecidos "califican de acción subversiva todo intento de cambiar un sistema social que favorece la permenencia de sus privilegios... Les será muy fácil encontrar aparenres justificaciones ideologicas (vg. anticomunismo) o práclicas (conservación del orden) para cohonestar este proceder" (Medellin, Paz, 6). Ver también Pucbla No. 92: "El 1emor del marxismo impide a muchos enfrentar la realidad opresiva del capitalismo liberal. Se puede decir que, ante el peligro de un sistema claramente marcado por el pecado, se olvida denunciar y combatir la realidad implantada por otro sistema igualmente marcado por el pecado" (subrayados mios).

23. En mi modesta opinión es preciso estar ciegos o querer estarlo, para no reconocer que en la actual sociedad norteamericana, y a través de ella en menor grado también en codo el mundo occidental que ella coloniza culturalmente, no existe ningún valor humano que tenga, ni de lejos, las cotas de implantación y de aprecio que tiene el "valor" agresividad y violencia: una violencia presentada como medio de defense de la libertad y el orden, pero asimilada y vivida secretamente como medio de afirmación de si mismo a traves del enriquecimiento.

24. P. Guilluy, op cir. (en nota 20), p. 170.

25. Cristionismo. ¿Opio o liberación?. Salamanca, 1972, p. 123.

26. Según la magnifica definición de P. Schoonenberg en Mysterium Salutis II, II. Madrid, 1970, p. 977 . Vease toda esta página.

27. La expresión es también de P. Schoonenberg (loc, cit.) a quien compete el mérito de haber recuperado para la teologle la noción de pecado estructural. Ver igualmente, de este mismo autor El poder del pecado, Buenos Aires, 1968. Aqui podemos prescindir de la polémica desalada sobre la presunta identilicación entre "situación" y pecado original, y sobre el progresivo enriquecimiento. 
28. Este proceso está bien puesto de relieve en esta doble cita testimonial de la más reciente historia de un pais y de una lglesia concretos:

"Recuerdo de aquella elección de Miss Universo en San Salvador, cuando la policia recogia de las calles a los cipotes hambrientos y panzones para que no deslucieran las fiestas, cuando las misses, pocas horas antes en bikini, fueron llevadas a la Caredral de San Miguel, cuando se hablaba de dia y de noche del "pais de la sonrisa" que daba la bienvenida a aquellas mujeres....Alli supimos ver todos, de manera nítida el pecado del mundo revestido de falsa bellera y falsa alegría. Y fue entonces cuando entendimos que los acólitos de nuestras comunidades debian detenerse en todos los caminos de nuestra patria a asistir a los samarilanos heridos por el sistema, ciertos de que si eran necesitados era porque un punito de acomodados los habia marginados, ciertos de que si habia pobres, tan pobres en El Salvador, era porque había ricos, unos cuantos ricos que todo lo acaparaban."

"Y nadie en la comunidad tuvo la respuesta, porque la única era crucl: el plan de uno es la muerte del otro. Recuerdo que fue a partir de ahi cuando empezamos a reflexionar más profundamente sobre el pecado personal y sobre lo que son las esiruciuras de pecado. Ese "pecado del mundo" 'del que habla Juan en su evangelio y que está tan fuertementc enraizado en la sociedad capitalista. En una situación de desempleo generalizado, como es la que marca la historia salvadoreha, el que encuentra trabajo se lo está quitando a otro. Sin que haya culpa personal, todos estamos arrasirados por ese pecado, que es morial, porque trae muerte a muchos. El que alcanza a ir a la escuela le quila el lugar a ouro. el que vive en casa propia limita el que otros la tengan, el que logre ser atendido por un médico le quita el sitio al otro. Frente a todo esto nos sentíamos impotentes. Todos estábamos amarrados por la cuerda del pecado, lodos encadenados por este sistema pecaminoso que sirve al dios dinero. Nuestros arquitectos sólo construyen casas para los que pueden pagarlas, los médicos sólo curan a los que les pagan la consulta, las escuelas sólo abren su puerıa a los que alcanzan a cubrir la cuota, nuestras mejores tierras se dedican a la siembra de productos de exportación que sean rentables, mientras la gente liene hambre y hay que importar frijoles y arroz."

La fe un pueblo. Historia de una comunidad cristiana en El Salvador, Sall Salvador: UCA Editores 1984, pp. 84 y 74).

29. Algo parecido se podría decir de la información (ver p. ej. M. Vásquez Montalbán, Informe sobre la informacion, Barcelona, 1963). La información decide en parte muy considerable la conducta del hombre ante lo social. Imaginemos que en el telediario de cada día se nos dijese: hoy han muerto de hambre $\mathbf{1 2 0 . 0 0 0}$ personas; $\mathbf{5 0 . 0 0 0}$ niños menores de diez años han ido a la escuela sin comer, para que comiensen sus hermanitos; tantos miles han fallecido puramente por no tener asistencia médica... Todo esto son noticias muy reales y muy diarias y mucho más importantes que si un presidente ha recibido a otro, o si una miss universo tiene unas medidas mejores que otra. Pero, si un individuo aislado quisiera dar esas noticias, no podria; agencias y telelipos no transmiten esa clase de información. Y si lograra darlas, nosolros mismos apagariamos el televisor por no soportar tal género de noricias. La desinformación estructurada y el pecado estructural cuenian en alto grado con nuesira propia complicidad.

30. Esta pregunta de la escuela de Franklun recobra toda su crudeza cuando se la enmerca en cualesyuiera de los textos programáticos de la modernidad, y en sus mesiánicas esperanzas depositada en el binomio razón-libertad. Asi, por ejemplo, en las siguientes palabras de A. Condorcet en su Esbozo de una historia del progreso del espiriru humano: "Llegará pues el momento en que el sol sobre la tierra no iluminará más que a hombres libres, que no reconoceran otro maestro que su razon; en que los tiranos y los esclavos, los sacerdotes y sus instrumentos estúpidos o hipócritas ya no existirán más que en la historia y en los teatros; en que ya nadie se ocupará de ellos más que para llorar sus viclimas y sus engaños, o para dejarse guiar por el horror de sus excesos hacia una vigilancia útil, para saber reconocer, y ahogar bajo el peso de la razón, los primeros gérmenes de la superstición y la tirania si es que se atrevieran a reaparecer" (Dixieme époque).

31. De forma parecida, y aludiendo a la escuela de Frankfurt J. B. Metz, habla de un "desleimiento de la ilustración en burguesia." cfr. La fe en la historia y en la sociedad, p. 47.

32. Es inmensa la bibliografia sobre la primera generación de lo que se llama escuela de Frankfurt o 'teorla crfica de la sociedad:' Para no alargar innecesariamente esta nota, digamos que, en el contexto del apéndice que hemos presentado, puede ser útil remilir a E. Fromm, Pricoandlisis de la sociedad contemporánea; $\mathrm{H}$. Marcuse, El hombre unidimensional y M. Horkheimer - T. Adorno, Dielécrica de la llustracion. 